\title{
Trends of e-Government Research. Contextualization and Research Opportunities
}

\author{
Manuel Pedro Rodríguez Bolívar. University of Granada. Spain. manuelp@ugr.es
}

Laura Alcaide Muñoz. University of Granada. Spain. lauaraam@ugr.es

Antonio M. López Hernández. University of Granada. Spain. alopezh@ugr.es

\begin{abstract}
E-Government is a broad research field in which researchers are currently involved in a range of different research projects. Our purpose in this paper is to assist researchers in the development and direction of future analyses, identifying trends in terms of research and the methodology used. Universities and departments that make the main scientific contributions are identified, in order to locate and contextualize the research carried out into e-Government and to enhance intercommunication among researchers and thus knowledge in this field. To achieve this goal, we examined periodical publications listed in the Social Science Citation Index (SSCI) of the Institute for Scientific Information (ISI) in the fields of Public Administration and Information Science, during the period 2000-2009. Knowledge gaps and research opportunities have been derived, highlighting the need to use quantitative methodologies and to identify key factors to promote a theoretical framework to enhance the efficient implementation of e-Government, as well as identification the main universities where the researchers can complete their doctoral academic training.
\end{abstract}

Keywords: e-Government research; bibliometric study; Information Science; Public Administration.

\section{INTRODUCTION}

Since the term 'bibliometric' was first proposed by Alan Pritchard in 1969, many references to bibliometric studies have been made in the academic literature. It is considered that the systematic study of trends in a discipline is justified as an exercise of 
self-reflection to determine its historical roots (Atkins, 1988) and to predict research trends in the future (Löfstedt, 2005), with the consequent potential for research in any field of study.

Thus, in Information Science and Library Science, many such studies aim to achieve a better understanding of methodological approaches (Nour, 1985), examining a diversity of subjects in Information Systems research (González et al., 2000) and analysing doctoral dissertations in the field of public administration in order to evaluate the usefulness of the main approaches and concepts used (McCurdy \& Cleary, 1984). Others have focused on the literature review published in a single journal to discover trends in research and the methodology used (Harter \& Hooten, 1992).

In any case, a literature review is of overriding relevance in interdisciplinary fields of research in which research studies are published in journals listed in different categories. Such a review could provide an excellent overview of the current state of the art and thus enable a profound analysis of the contribution and methodologies used in that particular research field. This is the case of the field of e-Government, a broad research field in which researchers are currently involved in a range of different research projects and which, in recent decades, has generated an increasing volume of research literature (Grönlund, 2004).

Nonetheless, in the field of e-Government, available bibliometric studies are rare, recent, and partial; the papers analysed are those presented at scientific conferences in Europe, together with articles published in certain journals (Yildiz, 2007; Heeks \& Bailur, 2007). Thus, the conclusions drawn are liable to be biased. Therefore, given the great heterogeneity in the literature on the subject of e-Government and the absence of a broad bibliographical overview of this question in the fields of Information Science and Library Science, and of Public Administration, it is necessary to analyse the main contributions made in order to lay a solid foundation for future research in this respect.

Accordingly, the ambition of this paper is to assist researchers in the development and direction of future analyses, identifying trends in terms of research and the methodology used. Furthermore, we identify universities and departments that have produced the main articles, in order to locate and contextualize the research carried out into e-Government and to enhance intercommunication among researchers and thus knowledge in this field. To achieve this aim, this paper examines the institutional affiliations of the authors, the precise subject of their e-Government research and the methodologies used in the relevant articles published in the main journals included in the ISI index, highlighting potential 
opportunities for research in the field, in the belief that analysing the past will allow us to prepare for the future (Webster \& Watson, 2002).

The remainder of this paper is organized as follows. In the next section, a literature review related to relevant bibliometric studies is performed. In section three, the research methodology used is outlined, and then the results obtained in the empirical research are analysed. Finally, the main conclusions of this study are summarized and some questions on future trends in this area are highlighted for discussion.

\section{LITERATURE REVIEW}

The academic literature describes a great deal of research based on informetric research tools, and specifically bibliometric methodology; accordingly, there is lively debate and discussion in this field, concerning both the subject matter itself and the most appropriate way to approach the question. These reviews enable members of the academic community to identify the historical roots of a particular field of study (Atkins, 1988), to predict future research trends (Löfstedt, 2005), and to discern the direction taken in a discipline, possible inadequacies in methodology, weaknesses, trivial approaches, etc., in summary, a starting point which greatly facilitates the enhancement of knowledge.

In these sense, McCurdy \& Cleary (1984) analysed a series of doctoral dissertations, critically examining both the scope and the usefulness of the main approaches and concepts used. They considered the problems posed and highlighted the existence of methodological weaknesses and trivial approaches, together with the insignificance of many of the subjects analysed, concluding that such studies would have little impact on the development of a field of research. Indeed, Stallings and Ferris (1988) stated that, at the time of writing, attempts to conduct research had initially been directed at conceptualizing problems, mapping out possible areas of research and describing the objects in question, often using inappropriate methodology. Cleary (2000), however, observed a significant advance in research and a notable increase in the use of $\mathrm{PhDs}$ as a research tool and noted a greater quality in the doctoral research carried out by students.

Nevertheless, this problem in terms of the initial quality of research is not limited to PhDs but extends to other work, published in journals, as shown by the analysis carried out on articles found in international impact journals (Lan \& Anders, 2000; Plümper \& Radaelli, 2004). Stalling \& Ferris (1988) and Houston \& Delevan (1990) stated that highly rated journals were the main source of dissemination of academic research. 
Furthermore, they indicated that the cause of the low quality of research was mainly the excessive use of qualitative methods such as case studies and non-empirical research. They concluded that a change in research methodology was needed if it were to reach its full maturity as an academic field, since research should be based on the development of empirical theory and not be merely a reflection of current reality (Houston \& Delevan, 1990). Although both quantitative and qualitative approaches contribute to the science of knowledge, there is a clear need for more studies to accept and apply quantitative research methods rather than qualitative ones (Bailey, 1992), in view of the belief that quantitative empirical methods are more precise and objective for this purpose.

In the field of e-Government, until recently very few bibliometric studies had been carried out. Yildiz (2007) discusses the limitations of prior research in this area, such as vagueness in the definition of e-Government, and points out the need for empirical studies which would lead to new theoretical arguments in addition to new concepts and categories. Heeks \& Bailur (2007) focus their analysis on perspectives regarding eGovernment, research philosophy and the use of theory, analysing only academic talks given at scientific conferences in Europe and articles published in two journals listed on the ISI index, thus giving a partial analysis of this question. However, we intend to go further, making a complete and thorough review, identifying the departments and universities which make the main scientific contributions, and localize the research carried out in the field of e-Government with the ambition that researchers may make use of our results to establish relationships that promote the maturity of this topic, and exploit possible synergies.

\section{RESEARCH METHODOLOGY}

As indicated above, some previous studies have examined doctoral dissertations or their summaries, books or other sources of knowledge dissemination (Rice et al., 2002). However, we have preferred to use English-language academic and/or professional journals with major international impact (Braadbaart \& Yusnandarshah, 2008). The main reason for this decision is that the importance of the book as a vehicle of communication has been weakened over time (Ullah et al., 2008), and it is being replaced by the use of online sources (Kriebel \& Lapham, 2008), like e-journals, which are increasingly used by academics both for acquiring and for disseminating new knowledge (Nord \& Nord, 1995). 
In this sense, Bowman \& Hajjar (1978) observed that there are many books which are included in these journals in summary form and that these abstracts have been subjected to a rigorous review process. Through these assessments, journals not only set quality standards (Kellough \& Pitts, 2005) but also provide a filter, thus establishing the nature and scope of the ideas presented to the academic community (Forrester \& Watson, 1994). Therefore, it is possible to conclude that journals are a valid indicator of the quality of academic productivity (Legge \& Devore, 1987).

Moreover, following Lan \& Anders (2000), the present study excludes the analysis of editorials, brief communications, letters to the editor, symposiums, articles of a professional nature and book reviews, as we believe they offer a limited view of the subject addressed. Nevertheless, in the course of our research, we have taken into account articles included in special editions of journals, since they reflect more extensive research in certain subjects and the need to study these further.

It seems logical that an important element of the research carried out in e-Government should have been published in journals listed in the fields of Information Science and Library Science, and of Public Administration in view of the stated aims of the journals included in these categories. Therefore, this paper focuses on e-Government studies included in leading world journals listed in connection with these subjects.

We have used objective criteria such as the citation rate, impact factor, immediacy index and number of source items (Gordon, 1982) as references to select the journals with which to carry out our analysis. The reason for this choice is to avoid the bias found when subjective criteria are used (Vocino \& Elliott, 1982), although it is true that objective indicators, too, are not without their critics (Cameron, 2005). Nevertheless, Garfield (1972) defended the use of indicators based on the citation methodology because they provide useful data.

Regarding the selection of articles, and unlike Wright et al., (2004), we have reviewed all the articles in each of the journals that meet the conditions described above. To do this, the title and the abstract (Land \& Anders, 2000; Plümper \& Radaelli, 2004), the keywords (Hartley \& Kostoff, 2003), and the introduction of the articles to analyse the research objective were relevant factors in this process. In the few cases in which the application of these discrimination criteria was not enough, we have read the entire article. This exhaustive selection procedure was conducted separately by the three authors, to ensure the greatest objectivity. After selecting all articles, each author did his 
own cataloguing separately; the authors then met on several occasions to discuss the results, and to reach an agreement where discrepancies arose.

As a consequence of this somewhat laborious process, from a data base initially composed of 15,487 articles published in 40 periodical publications - which have among their aims the implementation of ICTs in public administrations and public management listed in ISI in the fields of Information Science and Library Science (15), and Public Administration (25), during the period 2000-2009, 426 met the selection criteria established and focused on e-Government. We paid attention to journals which show a special preference for the publication of articles about e-Government, selecting a group of them that involve the third quartile in both fields of research (see Table 1) with a final sample of 321 articles published in the two fields analyzed.

\begin{tabular}{|c|c|c|c|c|}
\hline Rank & Abbreviated Journal Title & $\begin{array}{c}\text { Impact Factor } \\
2008\end{array}$ & Total & $\begin{array}{c}\text { e-Government } \\
\text { articles }\end{array}$ \\
\hline \multicolumn{5}{|c|}{ PUBLIC ADMINISTRATION } \\
\hline 3 & PUBLIC ADMIN REV & 1.503 & 710 & 27 \\
\hline 16 & AM REV PUBLIC ADM & 0.633 & 243 & 24 \\
\hline 15 & INT REV ADM SCI & 0.710 & 325 & 18 \\
\hline 25 & PUBLIC ADMIN DEVELOP & 0.306 & 333 & 14 \\
\hline 6 & PUBLIC ADMIN & 1.269 & 435 & 12 \\
\hline 2 & J PUBL ADM RES THEOR & 1.509 & 273 & 11 \\
\hline 11 & ADMIN SOC & 0.941 & 304 & 11 \\
\hline 23 & PUBLIC MONEY MANAGE & 0.438 & 377 & 9 \\
\hline 8 & GOVERNANCE & 1.137 & 232 & 8 \\
\hline 12 & PUBLIC MANAG REV & 0.930 & 301 & 8 \\
\hline 18 & AUST J PUBLIC ADMIN & 0.590 & 306 & 7 \\
\hline 20 & LOCAL GOV STUD & 0.514 & 283 & 6 \\
\hline 13 & ENVIRON PLANN C & 0.727 & 512 & 3 \\
\hline 20 & POLICY POLIT & 0.514 & 334 & 2 \\
\hline 14 & J SOC POLICY & 0.726 & 279 & 2 \\
\hline 19 & POLICY STUD J & 0.574 & 278 & 1 \\
\hline 1 & J EUR PUBLIC POLICY & 1.806 & 483 & 0 \\
\hline 4 & PHILOS PUBLIC AFF & 1.500 & 135 & 0 \\
\hline 5 & J POLICY ANAL MANAG & 1.377 & 256 & 0 \\
\hline 7 & J EUR SOC POLICY & 1.164 & 171 & 0 \\
\hline 9 & CLIM POLICY & 1.135 & 223 & 0 \\
\hline 10 & POLICY SCI & 1.091 & 153 & 0 \\
\hline 17 & J HOMEL SECUR EMERG & 0.604 & 86 & 0 \\
\hline 22 & CONTEMP ECON POLICY & 0.456 & 392 & 0 \\
\hline 24 & PUBLIC PERS MANAGE & 0.383 & 292 & 0 \\
\hline \multicolumn{2}{|c|}{ PUBLIC ADMINISTRATION TOTAL } & & 7,716 & $163(38.26 \%)$ \\
\hline
\end{tabular}

Table 1. Articles on e-Government found in each ISI journal (2000-2009) 


\begin{tabular}{llccc}
\hline \multicolumn{2}{l}{ INFORMATION SCIENCE } & & & \\
12 & GOV INFORM Q & 1.910 & 228 & 136 \\
32 & SOC SCI COMPUT REV & 0.714 & 345 & 26 \\
27 & INFORM SOC & 1.042 & 399 & 19 \\
20 & J GLOB INF MANAG & 1.387 & 105 & 12 \\
13 & J COMPUT-MEDIAT COMM & 1.901 & 543 & 11 \\
5 & INFORM MANAGE-AMSTER & 2.358 & 1,874 & 10 \\
21 & TELECOMMUN POLICY & 1.244 & 346 & 10 \\
18 & J INFOR SCI & 1.648 & 479 & 9 \\
25 & ONLINE INFORM REV & 1.103 & 187 & 9 \\
26 & INT J INFORM MANAGE & 1.043 & 347 & 9 \\
4 & INFORM SYST J & 2.375 & 400 & 7 \\
5 & J MANGE INFORM SYST & 2.358 & 1,870 & 4 \\
28 & INFORM RES & 1.000 & 224 & 1 \\
8 & INFORM SYST RES & 2.261 & 235 & 0 \\
10 & J INF TECHNOL & 1.966 & 189 & 0 \\
\hline INFORMATION SCIENCE TOTAL & & 7,771 & $263(61.74 \%)$ \\
\hline TOTAL & & & 15,487 & $426(2.75 \%)$ \\
\hline
\end{tabular}

Table 1. Articles on e-Government found in each ISI journal (2000-2009) (continuation)

With the express aim of meeting the goals established for this paper, each of the articles included in our data base was classified, using MS Excel software, by the year of publication, the journal title, the institutional affiliation of the authors (departments and universities), the main subject dealt with and the principal methodology used. When the articles examined multiple research topics and/or used multiple methods, double counting was avoided by focusing only on the main research item and methodology used. To ensure this, it was essential to identify the main aim of the paper.

To determine the subjects addressed and methodologies applied, the authors conducted a content analysis of each article separately. The content analysis method is considered appropriate because it exhibits the following characteristics: (a) systematic, following a planned approach, such as selecting export-related articles in accordance with explicit and defensible rules and examining their content in exactly the same way; (b) objective, adopting an explicit set of rules that minimizes the possibility of the findings reflecting the analyst's subjective predispositions, rather than the content of the articles under analysis; and (c) quantitative, measuring the extent of emphasis or omission of any given analytic category, thus increasing precision in conclusions drawn and permitting a more accurate description of results (Krippendorff, 1980).

Concretely, the process followed to determine the main categories has been as follows. First, the categories used have been selected and adapted from those previously used in 
public administration research by Bingham and Bowen (1994) and Lan and Anders (2000).

Nonetheless, this initial list was expanded due mainly to the e-government is a relatively new research field, and the initial list did not consider categories such as electronic or digital divide participation and resistance barriers to e-government, which are becoming relevant in the last years as a result of the implementation of e-government applications, on one hand, and the gap between people with effective access to digital and information technology, and those with very limited or no access at all, on the other. In fact, recent studies are analyzing the imbalance both in physical access to technology and the resources and skills needed to effectively participate as a digital citizen.

Therefore, in a second phase of our analysis, the content analysis was applied to determine new categories from those proposed in public administration research. To achieve this aim, an exploratory qualitative analysis was performed, which allowed us to test for the first time the data. During this phase of the research we used the QSR NVivo software package in its eighth edition, with the intention of automating the coding of items. Finally, the categories were established resulted both from the results of the use of the QSR NVivo software and from detailed discussions between the authors, since the literature contains a great diversity of research in the field of e-Government (see table 2).

\section{RESEARCH THEMES}

\footnotetext{
TECHNOLOGICAL INNOVATION AND MODERNIZATION IN PUBLIC ADMINISTRATION MANAGEMENT: These articles are focused on the different changes in public administrations that allow greater transparence in the activities of government and public services. Modernization of public administrations is result of the efforts of public managers for implementation of ICTs and constitution of administrative arquitectures that enable more effective and efficient management.
}

E-GOVERNMENT PROGRAMME/PROJECT EVALUATION AND POLICY ANALYSIS: This item includes articles that discussed the results of an evaluation of public programs related with initciatives of e-government and policies expansion of ITCs.

E-PARTICIPATION AND DIGITAL DEMOCRACY: This item includes articles that illustrated studies about emergent changes in the relationship between government and the citizen as result of e-government; as the new management models facilitate democratic partipation and use the innovative tools like that blogs, chats or electronic vote encourage integration the citizens in public decisions.

E-SERVICES: These articles are about the lively debate about the transformation in the delivering of public sector services, as e-government could contribute to enhance public sector services to be delivered in a more efficient way as well as the incentives to do it.

ACCOUNTABILITY, TRANSPARENCY AND DISSEMINATION OF INFORMATION: This research theme includes articles that discussed use more frequent guvernamental Web pages to communicate with citizens, achieving greater levels of disclosure of information to promote accountability of public managers online; as well as identified the main incentives that motive public candidates to dissemination of public financial statements. 


\section{RESEARCH THEMES}

BEHAVIOUR OF CITIZENS IN RELATION TO THE APPLICATIONS OF E-GOVERNMENT: This research theme includes articles that focused on trends user-centered study of the accessibility of e-government sites; studies about the characteristics of citizens who use ICTs to communicate with public administrations, citizen's behavior in the use of the information posted on the guvernamental Web sites, and the different attitudes of citizens against governemnt in the used the media tools.

E-GOVERNMENT AND PERSONNEL / HUMAN RESOURCES: These articles are focused on the experiences of designers of gubernamental Web pages; the acceptance of ICTs by public officials, as well as the challenges and efforts made by public administrations in the management of ICTs.

LEGISLATIVE ARCHITECTURE: This research includes articles focused on administrative proceedings or any type of law that enables and encourages the adoption and implementation of e-government initiatives in public administrations.

INTERGOVERNMENTAL RELATIONS: This research theme includes articles that focused on the political or institutional aspects of interagency relations between governmental units at the local, state, or national level.

DIGITAL DIVIDE AND RESISTANCE BARRIERS TO E-GOVERNMENT: This item includes articles that illustrated studies about obstacles presented by the different applications available to citizens, existing national programs to educate citizens to integrate ICTs in their dialy lifes, discovering its many benefits, as well as the evaluation of guvernamental Web sites to discover problems accessibility of these disabled by offering solutions.

ORGANIZATIONAL THEORY AND BEHAVIOUR: These articles are about models of innovation adoption that integrates the internal and external organizational factors, implementation factors exists in system of governance (organizational obstacles), application of business methods for the selection of investments of ICTs in the public administrations (financing challenges) as well as following the changes in the structures of public executive administrations.

Table 2. Different Sub-categories about e-government (continuation)

\section{ANALYSIS OF RESULTS}

\subsection{Evolution in the e-Government research and methodologies used}

Interest in the implementation of ICTs in the area of public administration has been reflected in a gradual increase in the research carried out in the field of e-Government over the last few years (see Graph 1), especially regarding deliberative democracy (19\%), technological innovation and modernization in the management of public administration (16.20\%), e-Government programme/project evaluation and policy analysis (13.71\%) and accountability, transparency and dissemination of information (12.46\%) (see Table 3).

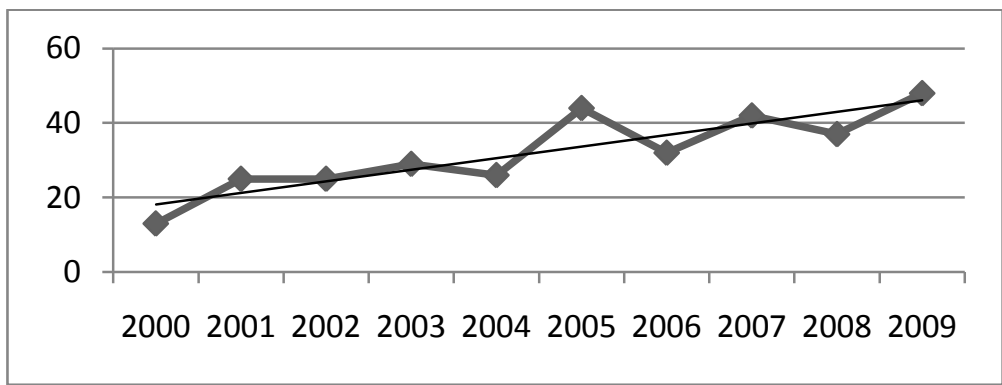

Graph 1. Time sequence for articles on e-Government (2000-2009) 
Nevertheless, the presence of e-Government research is still scarce, with the articles published in this field in ISI-listed journals only making up $2.75 \%$ of all published articles, and the majority of these (61.74\%) are in the field of Information Science and Library Science. There is a clear preference for one journal in the field of Information Science and Library Science to publish this type of research, with more than half of the articles $(51.71 \%, \mathrm{n}=136)$ being published in Government Information Quarterly, and in the field of Public Administration there is a preference for two journals, Public Administration Review and American Review of Public Administration, which account for $31.29 \%$ of the articles published (see Table 1).

\begin{tabular}{|c|c|c|c|c|c|c|c|c|c|c|c|}
\hline $\begin{array}{l}\text { Research Themes / } \\
\text { Years }\end{array}$ & 2000 & 2001 & 2002 & 2003 & 2004 & 2005 & 2006 & 2007 & 2008 & 2009 & Total \\
\hline $\begin{array}{l}\text { Technological innovation } \\
\text { and modernization in } \\
\text { public administration } \\
\text { management }\end{array}$ & 2 & 6 & 8 & 2 & 5 & 5 & 12 & 8 & 1 & 3 & $52(16.20 \%)$ \\
\hline $\begin{array}{l}\text { e-Government } \\
\text { programme/project } \\
\text { evaluation and policy } \\
\text { analysis }\end{array}$ & 2 & 3 & 4 & 2 & 4 & 7 & 1 & 7 & 9 & 5 & $44(13.71 \%)$ \\
\hline $\begin{array}{l}\text { Citizen participation / } \\
\text { Deliberative Democracy }\end{array}$ & 1 & 2 & 1 & 13 & 4 & 8 & 7 & 6 & 9 & 10 & $61(19.00 \%)$ \\
\hline e-Services & 1 & 4 & 1 & 2 & 4 & 6 & 1 & 2 & 2 & 4 & $27(8.41 \%)$ \\
\hline $\begin{array}{l}\text { Accountability, } \\
\text { transparency and } \\
\text { dissemination of } \\
\text { information }\end{array}$ & 2 & 7 & 4 & 3 & 4 & 4 & 3 & 6 & 3 & 4 & $40(12.46 \%)$ \\
\hline $\begin{array}{l}\text { Behaviour of citizens in } \\
\text { relation to the } \\
\text { applications of e- } \\
\text { Government }\end{array}$ & 0 & 0 & 1 & 2 & 1 & 5 & 4 & 3 & 5 & 8 & $29(9.03 \%)$ \\
\hline $\begin{array}{l}\text { e-Government and } \\
\text { Personnel / Human } \\
\text { Resources }\end{array}$ & 0 & 1 & 1 & 0 & 1 & 3 & 1 & 2 & 3 & 5 & $17(5.30 \%)$ \\
\hline Legislative architecture & 3 & 0 & 3 & 2 & 1 & 4 & 0 & 0 & 1 & 3 & $17(5.30 \%)$ \\
\hline $\begin{array}{l}\text { Intergovernmental } \\
\text { Relations }\end{array}$ & 0 & 1 & 1 & 0 & 0 & 0 & 0 & 3 & 1 & 4 & $10(3.12 \%)$ \\
\hline $\begin{array}{l}\text { Digital divide and } \\
\text { resistance barriers to e- } \\
\text { Government }\end{array}$ & 0 & 0 & 0 & 2 & 1 & 0 & 2 & 2 & 0 & 1 & $8(2.49 \%)$ \\
\hline $\begin{array}{l}\text { Organizational theory and } \\
\text { behaviour }\end{array}$ & 2 & 1 & 1 & 1 & 1 & 2 & 1 & 3 & 3 & 1 & $16(4.98 \%)$ \\
\hline
\end{tabular}

Table 3. Chronological distribution of different subjects dealt with in e-Government 
On the other hand, there are subjects which have not been thoroughly examined in the ISI journals analyzed, such as digital divide and barriers of resistance to e-Government (2.49\%), intergovernmental relations (3.12\%), organizational theory and behaviour (4.98\%), legislative architecture (5.30\%) and e-Government and Human Resources $(5.30 \%)$ (see Table 3).

The reason for the apparent lack of interest in these subjects, on the whole, is not their lesser importance but rather the fact that they are often published and listed in different research fields, e.g., the legislative architecture articles are published in law journals, while studies of organizational theory or human resources may be included in management journals.

On the chronological evolution of given research topics (Table 3), it can be seen that among the main topics covered in the literature on e-Government, the participation of citizens in decision making shows a clear upward trend over the years, mainly due to the importance attached by Governments to promoting e-democracy and to reducing political corruption, encouraging transparency and the accountability of public managers (Shim \& Eom, 2009; Kim et al., 2009). Hence, research studies dealing with accountability, transparency and the dissemination of information have been conspicuously present from 2000 to 2009. On the other hand, articles on the modernization of governments have always been present, while those evaluating initiatives implemented by public administrations have increased over time. Similarly, the popularity of articles focusing on how e-Government initiatives are perceived by citizens has increased over time. However, citizens are not the only stakeholders, as public servants are a key part of eGovernment operations and their further development, and so research studies addressing the subject of human resources have proliferated since 2006.

Focusing on the methodology used in the articles published on e-Government, we observe a preference for the use of empirical research methods $(86.29 \% ; 277 / 321)$ over non-empirical ones $(13.71 \%$; 44/321). The modernization of the public administration management $(31.82 \%)$ and the participation of citizens in public life $(27.27 \%)$ are research topics in which most non-empirical methods have been used. Among the qualitative tools, those most frequently used are case studies $(41.90 \%, \mathrm{n}=75)$, followed at a great distance by other qualitative methods, such as comparative analysis $(11.73 \%$, $\mathrm{n}=21)$ and content analysis $(11.17 \%, \mathrm{n}=20)$ (see table 4$)$. 


\begin{tabular}{|c|c|c|c|c|c|c|c|c|c|c|c|c|c|c|c|c|c|c|c|c|c|c|c|c|}
\hline \multirow[b]{2}{*}{$\begin{array}{l}\text { RESEARCH THEMES / } \\
\text { METHODOLOGIES }\end{array}$} & \multirow[b]{2}{*}{ 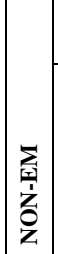 } & \multicolumn{13}{|c|}{ QUALITATIVE METHODOLOGIES } & \multicolumn{10}{|c|}{ QUANTITATIVE METHODOLOGIES } \\
\hline & & $\cong$ & 范 & $z$ & 紊 & z & 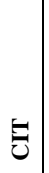 & 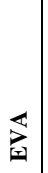 & 辤 & 空 & $\underset{\Xi}{\underline{\Xi}}$ & 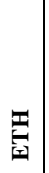 & 亥 & 䙓 & $\sum_{1}^{2}$ & 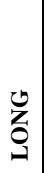 & 空 & 交 & 丟 & 已 & 在 & $\begin{array}{l}\text { 国 } \\
\text { 至 } \\
\text { 되 } \\
\end{array}$ & 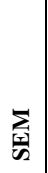 & 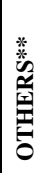 \\
\hline $\begin{array}{l}\text { Technological innovation } \\
\text { and modernization in public } \\
\text { administration management }\end{array}$ & 14 & 1 & 1 & 18 & 2 & 1 & & 1 & 1 & 1 & 1 & & & 2 & & 1 & 1 & 2 & 1 & 1 & 1 & 1 & & \\
\hline $\begin{array}{l}\text { e-Government } \\
\text { programme/project } \\
\text { evaluation and policy } \\
\text { analysis }\end{array}$ & 6 & & 1 & 12 & 3 & 3 & 3 & 2 & 2 & & 2 & & & 2 & & 1 & 4 & 1 & & & 2 & & & \\
\hline $\begin{array}{l}\text { Citizen participation / } \\
\text { Deliberative Democracy }\end{array}$ & 12 & & 1 & 9 & 2 & 4 & 1 & 3 & 1 & & 1 & 3 & & 1 & 1 & 2 & 6 & 3 & 4 & 2 & 3 & & 2 & \\
\hline e-Services & 1 & 1 & & 12 & 3 & & 1 & 1 & & 1 & & & & & & & 4 & 2 & 1 & & & & & \\
\hline $\begin{array}{l}\text { Accountability, } \\
\text { transparency and } \\
\text { dissemination of } \\
\text { information } \\
\end{array}$ & 4 & 1 & & 8 & 8 & 5 & 1 & 1 & 1 & 1 & 1 & & & 1 & & & 6 & & & & & & & 2 \\
\hline $\begin{array}{l}\text { Behaviour of citizens in } \\
\text { relation to the applications } \\
\text { of e-Government }\end{array}$ & & & & & & & 1 & 1 & & & & & & 1 & & 1 & 8 & & 1 & & 3 & 1 & 10 & 2 \\
\hline $\begin{array}{l}\text { e-Government and } \\
\text { Personnel / Human } \\
\text { Resources }\end{array}$ & & & & 4 & 1 & 2 & & 1 & & & & & & & & & 2 & & & & 1 & 1 & 3 & 2 \\
\hline Legislative architecture & & & & 2 & & 4 & & 2 & 1 & & 4 & & 3 & & & & 1 & & & & & & & \\
\hline $\begin{array}{l}\text { Intergovernmental } \\
\text { Relations }\end{array}$ & 2 & & & 5 & 1 & & & 1 & & & & & & & & & 1 & & & & & & & \\
\hline $\begin{array}{l}\text { Digital divide and } \\
\text { resistance barriers to e- } \\
\text { Government }\end{array}$ & 2 & & & 1 & & 1 & & & & 2 & & & & & & & 1 & 1 & & & & & & \\
\hline $\begin{array}{l}\text { Organizational theory and } \\
\text { behaviour }\end{array}$ & 3 & & & 4 & 1 & 1 & 1 & & & & & & & 2 & 1 & & 3 & & & & & & & \\
\hline TOTAL & $\#$ & 3 & 3 & 75 & 21 & \# & 8 & 14 & 6 & 5 & 9 & 3 & 3 & 9 & 2 & 5 & 37 & 9 & 7 & 3 & 10 & 3 & 16 & 6 \\
\hline \multicolumn{25}{|c|}{ * SNA(1); MARK (1); SCE (1); CONT (1); FEA (1); HOL (2); LONG (2) } \\
\hline
\end{tabular}

Table 4. Methodologies used to analyze each of the phenomena related to e-Government

In this sense, the case studies have been used to discuss any research area, although there is a certain predilection for their use in the analysis of modernization in public administration management (24\%), in the analysis of e-Government projects (16\%), and examining the provision of traditional public services via Internet (16\%). Meanwhile, comparative analysis and content analysis are used for accountability, transparency and dissemination of information research in $38.09 \%$ and $25 \%$, respectively, of the studies considered. 
List of abbreviations METHODOLOGIES

\begin{tabular}{llll}
\hline AR & Action-Research & HEU & Heuristic Approach \\
CS & Case Studies & INFOR & Informetric Studies \\
CONAN & Content Analysis & LHM & Life History Method \\
COMAN & Comparative Analysis & LONG & Longitudinal Design \\
CIT & Critical Incident Technique & MARK & Marketing Technique \\
CHI & Chi-square Method & NON-EM & Non-empirical \\
ETH & Ethnographic Studies & NORM & Normative Approach \\
EVA & Evaluation Research & REG & Regression Analysis \\
FAC & Factorial Analysis & SCE & Scene Evaluation \\
FEA & Feasibility Studies & SNA & Social Network Analysis \\
HER & Hermeneutic Exploration & SEM & Structural Equation Model \\
HOL & Holistic Approach & & \\
\hline & & DEPARTMENTS & \\
\hline PA & Public Administration & MS & Management Science \\
P\&PS & Public and Political Science & CS & Computer Science and Information Systems \\
ACC & Accounting, Business and Economics & PRAC & Practitioners \\
LIS & Library and Information Science & MK & Marketing and Communication \\
\hline
\end{tabular}

Table 4. Methodologies used to analyze each of the phenomena related to e-Government (abbreviations)

The most widely used quantitative methodologies are regression analysis (37.76\%), followed at a great distance by structural equation models (16.33\%) and evaluation research $(10.20 \%$ ) (see table 4$)$. The regression analysis method is used on a great variety of subjects, especially those for which the researcher seeks to determine users' opinions and the factors that explain their behaviour and satisfaction, such as participatory democracy $(16.22 \%)$ or citizens' satisfaction in relation to the implementation of eGovernment (21.62\%). Similarly, the structural equation model is used in $62.5 \%$ of cases, in order to determine the constructors that influence users' satisfaction and the relations between these constructors. In summary, there is still a clear preference for the use of qualitative tools, although this trend seems to be weakening as time passes, i.e. researchers are increasingly relying on quantitative methodologies for analysing the phenomena of e-Government, at the expense of qualitative methodologies, as shown in Graph 2.

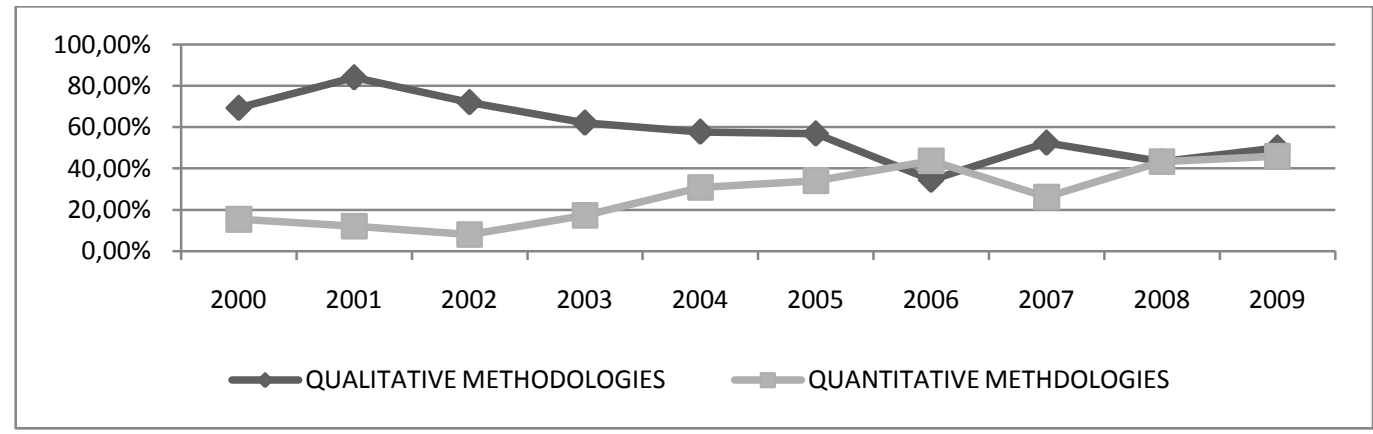

Graph 2. Temporal trends in the use of methodologies 


\subsection{Which institutions and academics departments research about e- Government?}

The largest body of research projects on e-Government published in journals of international impact (45.58\%) come from American universities (Table 5). Among the most active in this respect are public universities well known for their research, such as State University of New York at Albany (SUNY), Indiana University Bloomington, Iowa State University, University of Maryland, together with less renowned ones like University of Texas at San Antonio, University of Missouri and University of Wisconsin, and highly selective private universities such as University of Southern California (USC).

Next in numerical importance are European universities (29.36\%). Here, the majority of articles published about e-Government are produced by universities in the United Kingdom (29.52\%), the Netherlands (27.47\%) and Spain (15.35\%). Among the most representative British universities are those of Manchester, De Montfort, Birmingham and Cranfield, while the universities of Utrecht, Erasmus Rotterdam and Twente are the main contributors of such research articles in the Netherlands. In the Spanish case, there are two pioneer universities in the field, namely Granada and Zaragoza.

Nevertheless, research studies do not only come from the USA and Europe. Universities in Taiwan produce about one quarter of the academic contributions made by the Asian continent (15.64\% of the global volume), among the most productive of which are private universities such as National Chung Hua and Shin-Hsing, and public universities such as National Changhua and National Chung Cheng. Similarly, eGovernment studies have been made by universities in Canada (4.45\%), Australia (2.20\%) and New Zealand (1.39\%); on the other hand, the contributions of South American and African universities ( $0.93 \%$ and $0.46 \%$, respectively) are very low.

\begin{tabular}{|c|c|c|c|c|c|c|c|c|c|c|c|}
\hline $\begin{array}{l}\text { Research Themes / Countries of } \\
\text { the Universities }\end{array}$ & s. & 弚 & 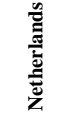 & 苋 & 䔍 & 龍 & 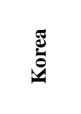 & 音 & 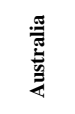 & 离 & 产 \\
\hline $\begin{array}{l}\text { Technological innovation and } \\
\text { modernization in public } \\
\text { administration management }\end{array}$ & $36.44 \%$ & $16.39 \%$ & $8.02 \%$ & $2.19 \%$ & $13.11 \%$ & $4.37 \%$ & $2.19 \%$ & & $5.09 \%$ & & $12.20 \%$ \\
\hline $\begin{array}{l}\text { e-Government programme/project } \\
\text { evaluation and policy analysis }\end{array}$ & $49.38 \%$ & $7.60 \%$ & $1.70 \%$ & $7.60 \%$ & $0.84 \%$ & & $0.84 \%$ & & $0.84 \%$ & $2.53 \%$ & $28.69 \%$ \\
\hline
\end{tabular}

Table 5. Research themes analysed in each of the countries and universities 


\begin{tabular}{|c|c|c|c|c|c|c|c|c|c|c|c|}
\hline $\begin{array}{l}\text { Research Themes / } \\
\text { Countries of the } \\
\text { Universities }\end{array}$ & USA & UK & Netherlands & Spain & Canada & Taiwan & Korea & Belgium & Australia & Turkey & Others \\
\hline $\begin{array}{l}\text { Citizen participation / } \\
\text { Deliberative Democracy }\end{array}$ & $47.33 \%$ & $17.61 \%$ & $10.57 \%$ & & $5.28 \%$ & $1.76 \%$ & $3.70 \%$ & $5.28 \%$ & $0.35 \%$ & & $8.10 \%$ \\
\hline e-Services & $54.17 \%$ & $4.17 \%$ & $4.17 \%$ & $12.50 \%$ & $4.17 \%$ & $2.08 \%$ & $2.08 \%$ & & $8.33 \%$ & & $8.33 \%$ \\
\hline $\begin{array}{l}\text { Accountability, } \\
\text { transparency and } \\
\text { dissemination of } \\
\text { information }\end{array}$ & $55.44 \%$ & $1.55 \%$ & $5.19 \%$ & $15.54 \%$ & & & $4.66 \%$ & $5.19 \%$ & & & $12.43 \%$ \\
\hline $\begin{array}{l}\text { Behaviour of citizens in } \\
\text { relation to the applications } \\
\text { of e-Government }\end{array}$ & $36.21 \%$ & & $10.34 \%$ & & $3.45 \%$ & $17.24 \%$ & & $6.90 \%$ & & $3.45 \%$ & $22.41 \%$ \\
\hline $\begin{array}{l}\text { e-Government and } \\
\text { Personnel / Human } \\
\text { Resources }\end{array}$ & $33.35 \%$ & $11.76 \%$ & $1.47 \%$ & & $5.88 \%$ & $5.88 \%$ & $5.88 \%$ & $4.41 \%$ & & $5.88 \%$ & $25.47 \%$ \\
\hline Legislative architecture & $53.85 \%$ & $7.69 \%$ & & & & & $7.69 \%$ & & & $7.69 \%$ & $23.08 \%$ \\
\hline $\begin{array}{l}\text { Intergovernmental } \\
\text { Relations }\end{array}$ & $43.30 \%$ & & $20.00 \%$ & $10.00 \%$ & $5.00 \%$ & & & & & & $21.70 \%$ \\
\hline $\begin{array}{l}\text { Digital divide and } \\
\text { resistance barriers to e- } \\
\text { Government }\end{array}$ & $33.33 \%$ & & $26.76 \%$ & & & & & & $13.33 \%$ & $13.33 \%$ & $13.33 \%$ \\
\hline $\begin{array}{l}\text { Organizational theory and } \\
\text { behaviour }\end{array}$ & $55.13 \%$ & & $21.82 \%$ & & & $3.64 \%$ & & & $3.64 \%$ & & $15.78 \%$ \\
\hline TOTAL & $45.58 \%$ & $8.67 \%$ & $8.06 \%$ & $4.51 \%$ & $4.45 \%$ & $3.47 \%$ & $2.58 \%$ & $2.57 \%$ & $2.20 \%$ & $1.73 \%$ & $16.18 \%$ \\
\hline
\end{tabular}

Table 5. Research themes analysed in each of the countries and universities (continuation)

The articles published are mostly produced (64.80\%) by two or more colleagues, usually from the same university (51.92\%), although it is not unusual to see collaborations between members of different universities, and also between universities in different countries. The authors are mostly men, with fewer than $30 \%$ of authors in the field of e-Government being women. The topic in question appears to be of interest to a diverse academic community, but there is a specialized domain for authors in the field of public administration (22.5\%) and public and policy sciences (15.2\%) (see Graph 3), while we observe the existence of heterogeneous knowledge areas such as Information Science and Library Science, Marketing and Communications and Computer Science.

Moreover, the collaboration of practitioners in this area of research represents a significant weight $(8.4 \%)$, thus endowing the article with practical vision and firsthand knowledge of the situation of many governmental agencies. These persons are usually civil servants and managers, affiliated to government departments like that department of defense, energy, information services or computer and telecommunication. We also find authors who serve on public foundations and public institutions, private companies and 
librarians employed in public libraries, like that Librarian of Congress and National Library in United State of American.

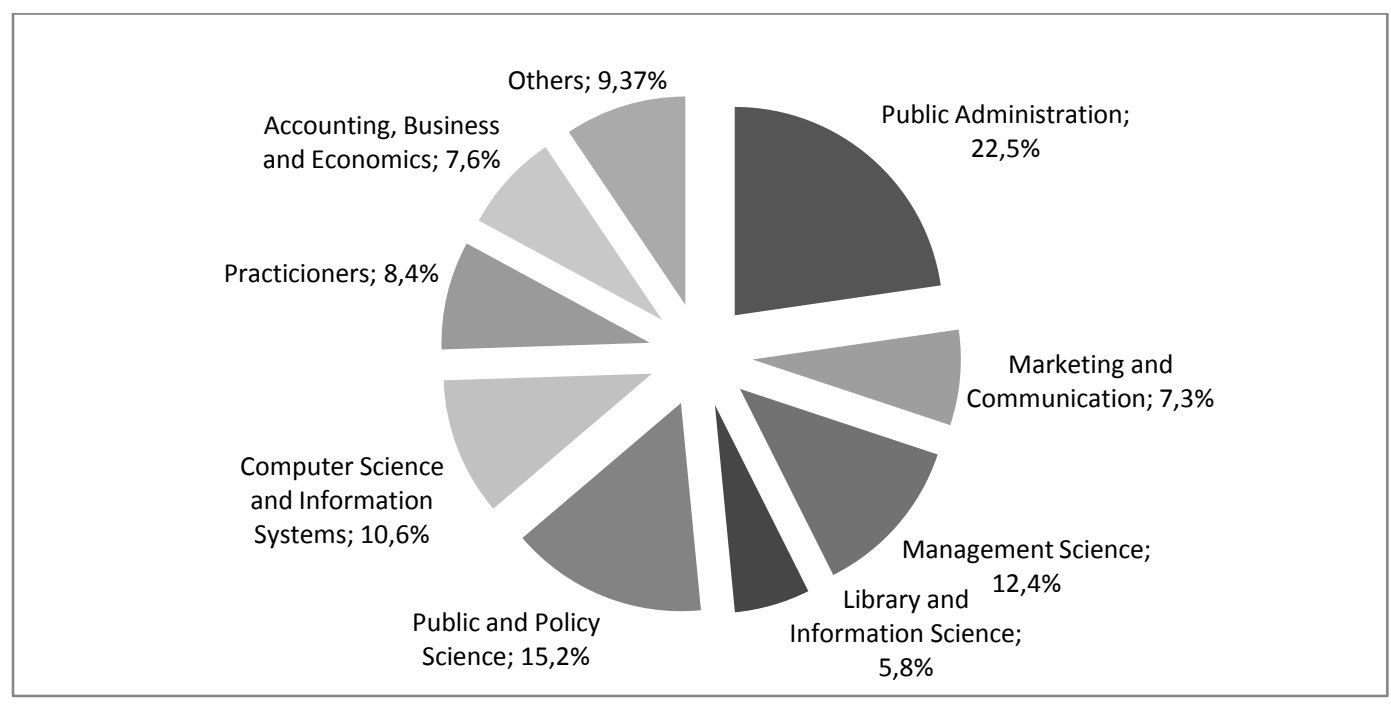

Graph 3. Academic departments which investigate e-Government

The articles written by practitioners are usually written with co-authors that are scholars and researchers $(57.90 \%)$. In addition, the findings of our study show that there are certain differences in the methodology used when practitioners undertake an investigation on its own or when it is undertaken jointly with scholars or researchers.

Thus, when the research is developed only by practitioners, it is non-empirical and qualitative methods are often used, whereas when the study is developed with a researcher, quantitative methodologies are used such as factor analysis, logistic regression analysis or analysis $(31.82 \%)$.

Table 6 shows that there is a clear preference for certain topics, in different areas of knowledge. For example, the department of Public Administration is focused on research into technological innovation in public management, citizens' participation online, analysis and evaluation of e-government programs and citizens' behaviour. In contrast, the articles dealing with barriers of resistance and the digital divide are researched mainly by departments of Marketing and Communication and of Information Science and Library Science, while these research subjects have not been examined by departments of Public Administration or Public and Policy Science. Similarly, departments of Marketing and Communication focus on legal issues related to the modernization of public agencies, 
the dissemination of information, web site design, data protection, etc., and departments of Political Science have contributed to research into the behaviour of civil servants and managers.

\begin{tabular}{|c|c|c|c|c|c|c|c|c|}
\hline $\begin{array}{l}\text { Research topic / the } \\
\text { main academic } \\
\text { department }\end{array}$ & PA & MS & P\&PS & CS & $\mathrm{ACC}$ & PRAC & LIS & MK \\
\hline $\begin{array}{l}\text { Technological innovation } \\
\text { and modernization in } \\
\text { public administration } \\
\text { management }\end{array}$ & $22.47 \%$ & $18.37 \%$ & $21.67 \%$ & $23.81 \%$ & $10.00 \%$ & $18.18 \%$ & $4.35 \%$ & $6.90 \%$ \\
\hline $\begin{array}{l}\text { e-Government } \\
\text { programme/project } \\
\text { evaluation and policy } \\
\text { analysis }\end{array}$ & $13.48 \%$ & $14.29 \%$ & $16.67 \%$ & $26.19 \%$ & $16.67 \%$ & $18.18 \%$ & $21.74 \%$ & $6.90 \%$ \\
\hline $\begin{array}{l}\text { Citizen participation / } \\
\text { Deliberative Democracy }\end{array}$ & $16.85 \%$ & $8.16 \%$ & $13.33 \%$ & & & $6.06 \%$ & & $3.45 \%$ \\
\hline e-Services & $4.49 \%$ & $8.16 \%$ & $10.00 \%$ & $7.14 \%$ & $16.67 \%$ & $15.15 \%$ & $17.39 \%$ & $10.34 \%$ \\
\hline $\begin{array}{l}\text { Accountability, } \\
\text { transparency and } \\
\text { dissemination of } \\
\text { information }\end{array}$ & $8.99 \%$ & $8.16 \%$ & $15.00 \%$ & $2.38 \%$ & $26.67 \%$ & $18.18 \%$ & $26.09 \%$ & $13.79 \%$ \\
\hline $\begin{array}{l}\text { Behaviour of citizens in } \\
\text { relation to the } \\
\text { applications of e- } \\
\text { Government }\end{array}$ & $12.36 \%$ & $18.37 \%$ & $5.00 \%$ & $16.67 \%$ & $3.33 \%$ & & $8.70 \%$ & $24.14 \%$ \\
\hline $\begin{array}{l}\text { e-Government and } \\
\text { Personnel / Human } \\
\text { Resources }\end{array}$ & $4.49 \%$ & $8.15 \%$ & $10.00 \%$ & $7.14 \%$ & $6.67 \%$ & & & $6.90 \%$ \\
\hline Legislative architecture & $4.49 \%$ & $4.08 \%$ & $3.33 \%$ & $2.38 \%$ & $3.33 \%$ & $15.15 \%$ & & $10.34 \%$ \\
\hline $\begin{array}{l}\text { Intergovernmental } \\
\text { Relations }\end{array}$ & $3.37 \%$ & $6.12 \%$ & $3.33 \%$ & $4.76 \%$ & $6.67 \%$ & & $8.70 \%$ & $3.45 \%$ \\
\hline $\begin{array}{l}\text { Digital divide and } \\
\text { resistance barriers to e- } \\
\text { Government }\end{array}$ & & & & $2.38 \%$ & $3.33 \%$ & & $8.70 \%$ & $10.34 \%$ \\
\hline $\begin{array}{l}\text { Organizational theory } \\
\text { and behaviour }\end{array}$ & $8.99 \%$ & $6.12 \%$ & $1.67 \%$ & $7.14 \%$ & $6.67 \%$ & $9.09 \%$ & $4.35 \%$ & $3.45 \%$ \\
\hline
\end{tabular}

Table 6. Research topics investigated by the main academic departments

Focusing on the origin of the research studies made, Table 5 shows that US universities produce all types of studies, although the main articles published concern: a) the accountability, transparency and dissemination of information (researched at SUNY at Albany, the University of Arizona and the University of Wisconsin); b) organizational theory, researched by Syracuse University, SUNY at Albany and Iowa University; and c) e-services and legislative architecture, studies on which are published by different universities, with no group or individual university standing out.

Focusing on universities from the United Kingdom, the main contributions are on the subject of citizens' participation (with contributions by researchers from the De Montfort 
University and Napier University, Edinburgh) and on technological innovation in the management of public administration, studied at the University of Manchester. In the Netherlands, most contributions concern organizational theory, resistance barriers and intergovernmental relations, with the University of Twente being the most representative on these subjects in this country. In Spain, most articles in this field address accountability, transparency, the dissemination of information and e-services, with these articles being written by researchers from the University of Granada in collaboration with others from the University of Almeria and from the University of Zaragoza.

In Canada, e-Government articles have been published on the transformation and reform of the public administrations with the implementation of ICTs; the most representative universities here are those of Toronto and Carleton University. Finally, in Taiwan, relevant articles are focused on the attitudes and behaviour of citizens and the increased trust of citizens in public servants. The authors of these articles are mainly from the National Changhua University of Education.

\section{DISCUSSION AND CONCLUSIONS}

Although the interest aroused by e-Government is apparent in the notable increase in studies published in leading journals with international impact, as included in the ISI index since 2000 (Grönlund \& Horan, 2005; Heeks \& Bailur, 2007), it remains the case that research in this field is at a very initial stage. Our paper is intended as a contribution to empirical literature, describing the current state of research into e-Government and providing a framework to assist public managers and researchers in future studies, as well as addressing the localization and contextualization of research into e-Government.

Among the subjects examined by researchers are deliberative democracy, the modernization of public administration management following the introduction of ICTs, the evaluation of public programmes related to e-Government initiatives and to ICT expansion policies, and the accountability, transparency and dissemination of information. The results published reflect a transformation of management systems within public administrations, through the implementation of e-Government. The latter process has enabled a greater provision of information over the Internet, enhanced services, streamlined transactions and two-way communication between the agency and the different stakeholders, as well as greater transparency in the management of public organizations and the disclosure of a greater volume of information on governmental websites. 
In this respect, currently there is a lively debate about the transformation in the delivering of public sector services (Osborne, 2009, 2010). As noted previously, eGovernment could contribute to enhance public sector services to be delivered in a more efficient way. So, further research in e-Government should investigate how the eGovernment processes could contribute to improve efficiency in the delivering of public sector services as well as the incentives to do it.

As regard to the communication with stakeholders, it has led to greater electronic democracy (e-participation) and the integration into the community of the political background to governmental decisions (e-decision making), without the need to form part of the public administration or to belong to a political party (Bingham et al., 2005; Chadwick \& May, 2003). In this respect, much is expected of studies focusing on eDemocracy, eGovernance, eDeliberation and eVoting, as well those examining the online dissemination of economic and financial information by public administrations, in order to promote greater transparency and citizens' participation in decision taking in the public sector. Recent studies have sought evidence of the use made by public administrations of their web sites as an instrument for information dissemination (Borins, 2002). They have also attempted to highlight deficiencies and identify the factors that determine different levels of openness and informational transparency (Serrano-Cinca et al., 2009; Caba et al., 2008).

As in other fields of knowledge (see Stalling \& Ferris, 1988; Houston \& Delevan, 1990) and due to the empirical and sociological nature of the field of public administration studies (Ragab, 2005), the main methodology used in research into eGovernment is empirical, with an emphasis on a qualitative approach. However, our results show that in recent years this pattern is changing, and that quantitative methods are increasingly favoured by researchers. Such methods require the estimation of causal relations via a combination of statistical techniques, such as factorial analysis, regression analysis and the structural equations model, which in general offer results that are more solid and reliable (Bailey, 1992).

In this regard, the analysis of the contextual factors in which the e-Government is developed could help to understand the underlying forces that enhance e-Government projects. In fact, although prior research has examined some factors related to eGovernment as a tool for disclosing governmental information, these studies have not been consistent neither on the variables nor on the measurement techniques used. Therefore, it is necessary to develop future research to identify statistically significant 
factors regardless considerations used in studies, with the aim of exerting influence over public managers when designing strategies for e-Government implementations.

This trend, as well as providing this incipient area of study with greater methodological support, reveals the growing necessity to offer conceptual frameworks and a theoretical foundation that will provide a basis for the efficient implementation of e-Government, as part of the process of modernization of public administrations. As Yildiz (2007) points out, one suggestion could be to explain the policy-making processes in e-Government projects in a complex political environment or to tie the subject of eGovernment strongly to mainstream public administration research. Indeed, the results of future studies might make the connection between e-Government and the traditional concerns of public administration stronger. In spite of this comment, our results show that new literature on old and new mainstream public administration concerns is beginning to become relevant in the last years, as for example, literature on the link between egovernment and intergovernmental relations (table 3).

On the other hand, the main publications in international impact journals come from US universities, followed closely by European universities, located in United Kingdom, the Netherlands and Spain, although it must be borne in mind that most of these articles are published in American journals. We also found articles from Asia, Canada, Australia and New Zealand. e-Government researchers often publish in collaboration with colleagues from the same university or from universities located in other countries, and most of them are men. These researchers are specialized in public administration and political science, although articles written by authors from areas such as Marketing, Information Science and Library Science, and Computer Science are also to be found, because e-Government is an interdisciplinary field.

The results achieved in this study show that many of the research fields in question are tightly specialized, and on occasion studies are associated with theoretical connotations of the same field of research. Scientific knowledge is enriched when an article is written by researchers specialized in the topic and possessing a solid theoretical background. However, we have also encountered studies published involving applied and theoretical research on topics that are not specific to the research fields of the respective authors, which may lead to the application of an inappropriate rationale and theoretical underpinning.

The research topics identified are mainly produced at certain specific universities; this circumstance allows future researchers to know beforehand the institution where they can 
complete their doctoral academic training, to decide where to enrol in doctoral programmes as well as where to seek advice regarding the chosen research topic.

To conclude, the review presented in this paper provides a comprehensive summary of the research into e-Government within the field of Information Science and Library Science, and Public Administration, highlighting the main research topics and methodologies used. Explanations and clarifications are given whenever possible. Knowledge gaps and research opportunities are identified from these observations, which reveal changes in the research methods applied, with a greater application of quantitative methods, thus reinforcing the development of a theoretical framework so that the application of e-Government may efficiently contribute to improving management in the public sector.

In this respect, it would be interesting to develop future studies of eParticipation, eDemocracy and eGovernance in order to identify key factors in the construction of efficient theoretical frameworks for the implementation of e-Government in public management.

\section{REFERENCES}

ATKINS, S. E. (1988): "Subject trends in library and information science research 19751984", Library Trends, vol. 36, n. 4: 633-658.

BAILEY, M. T. (1992): "Do Physicists Use Case Studies? Thoughts on Public Administration Research", Public Administration Review, vol. 52, n.1: 47-55. http://dx.doi.org/10.2307/976545

BINGHAM, L. B.; NABATCHI, T.; O'LEARY, R. (2005): “The new governance: Practices and processes for stakeholder and citizen participation in the work of government", Public Administration Review, vol. 65, n. 5: 547-558. http://dx.doi.org/10.1111/j.1540-6210.2005.00482.x

BINGHAM, R. D.; BOWEN, W. (1994): "Mainstream Public Administration over time: A Topical Content Analysis of Public Administration Review", Public Administration Review, vol. 54, n. 2: 204-208. http://dx.doi.org/10.2307/976531

BORINS, S. (2002): "On the frontiers of electronic governance: a report on the United States and Canada", International Review of Administrative Science, vol. 68, n. 2: 199211. http://dx.doi.org/10.1177/0020852302682003 
BOWMAN, J. S.; HAJJAR, S. G. (1978): "The Literature of American Public Administration: Its Contents and Contributors", Public Administration Review, vol. 38, n. 2: 156-165. http://dx.doi.org/10.2307/976291

BRAADBAART, O.; YUSNANDARSHAH, B. (2008): "Public Sector benchmarking: a survey of scientific articles, 1990-2005", International Review of Administrative Sciences, vol. 74, n. 3: 421-433. http://dx.doi.org/10.1177/0020852308095311

CABA, C.; RODRÍGUEZ, M. P.; LÓPEZ, A. M. (2008): "E-Government process and incentives for online public financial information", Online Information Review, vol. 32, n. 3: 379-400. http://dx.doi.org/10.1108/14684520810889682

CAMERON, B. D. (2005): "Trends in the Usage of ISI Bibliometric Data: Uses, Abuses, and Implications", Portal: Libraries and the Academy, vol. 5, n. 1: 105-125. http://dx.doi. org/10.1353/pla.2005.0003

CHADWICK, A.; MAY, C. (2003): "Interaction between states and citizens in the age of the Internet: e-Government in the United States, Britain, and the European Union", Governance: An International Journal of Policy and Administration, vol. 16, n. 2: 271300.

CLEARY, R. E. (2000): “The Public Administration Doctoral Dissertation Re-examined: An Evaluation of the Dissertations of 1998", Public Administration Review, vol. 60, n. 5: 446-455.

FORRESTER, J. P.; WATSON, S. S. (1994): “An Assessment of Public Administration Journals: The Perspective of Editors and Editorial Board Members", Public Administration Review, vol. 54, n. 5: 474-482. http://dx.doi.org/10.2307/976433

GARFIELD, E. (1972): “Citation analysis as a tool in journal evaluation”, Science, vol. 178, n. 60: 471-479. http://dx.doi.org/10.1126/science.178.4060.471

GONZALEZ, R.; CLAVER, E.; LLOPIS, J. (2000): "An analysis of research in information systems (1981-1997)", Information and Management, vol. 37, n. 4: 182-195.

GORDON, M. D. (1982): "Citation Ranking versus Subjective Evaluation in the Determination of Journal Hierarchies in the Social Sciences", Journal of the American Society for Information Science, vol. 33, n. 1: 55-57. http://dx.doi.org/10.1002/asi.463033 0109 
GRÖNLUND, A. (2004): "State of the art in e-Gov research -a survey", In Trammüller, R. (ed.), Electronic Government: Third International Conference, EGOV 2004. August $30^{\text {th }}-$ September $3^{\text {rd }}$.

GRÖNLUND, A.; HORAN, T. (2005): "Introducing e-gov: History, definitions and issues", Communications of the Association for Information Systems, vol. 15, article 39.

HARTER, S. P.; HOOTEN, P. A. (1992): "Information Science and Scientists: JASIS, 1972-1990", Journal of the American Society for Information Science, vol. 43, n. 9: 583593. http://dx.doi.org/10.1002/(SICI)1097-4571(199210)43:9\%3C583::AID-ASI1\%3E3.

0.CO;2-O

HARTLEY, J.; KOSTOFF, D. N. (2003): "How useful are "key words" in scientific journals?", Journal of Information Science, vol. 29, n. 5: 433-438. http://dx.doi.org/10.11 77/01655515030295008

HEEKS, R.; BAILUR, S. (2007): “Analysing e-Government research: Perspectives, philosophies, theories, methods, and practice", Government Information Quarterly, vol. 24, n. 1: 243-265. http://dx.doi.org/10.1016/j.giq.2006.06.005

HOUSTON, D. J.; DELEVAN, S. M. (1990): "Public Administration Research: An Assessment of Journal Publications", Public Administration Review, vol. 50, n. 6: 674681. http://dx.doi.org/10.2307/976978

KELlOUGH, J. E.; PITTS, D. W. (2005): "Who Contributes to Public Administration Review? Examining the Characteristics of Authors Who Submit Manuscripts to the Journal", Public Administration Review, vol. 65, n. 1: 3-7. http://dx.doi.org/10.1111/j.154 $\underline{0-6210.2005 .00425 . x}$

KIM, S.; KIM, H. J.; LEE, H. (2009): "An institutional analysis of an e-Government system for anti-corruption: The case of OPEN", Government Information Quarterly, vol. 26, n. 1: 42-50. http://dx.doi.org/10.1016/j.giq.2008.09.002

KRIEBEL, L.; LAPHAM, L. (2008): "Transition to Electronic Resources in Undergraduate Social Science Research. A Study of Honour Theses: Bibliographies, 1999-2005", College and Research Libraries, vol. 69, No. 3: 268-283.

KRIPPENDORFF, K. (1980). Content analysis: an introduction to its methodology. USA: Sage Publications, Inc. 
LAN, Z.; ANDERS, K. K. (2000): "A Paradigmatic View of Contemporary Public Administration Research: An Empirical Test", Administration and Society, vol. 32 n. 2: 138-165. http://dx.doi.org/10.1177/00953990022019380

LEGGE, J. S. Jr.; DEVORE, J. (1987): "Measuring Productivity in U.S. Public Administration and Public Affairs Programs 1981-1985", Administration and Society, vol. 19, n. 2: 147-156. http://dx.doi.org/10.1177/009539978701900201

LÖFSTEDT, U. (2005): "E-Government - Assessment of current research and some proposals for future direction", International Journal of Public Information Systems, vol. 1, n. 1: 39-52.

MCCURDY, H. E.; CLEARY, R. E. (1984): “A Call for Appropriate Methods”, Public Administration Review, vol. 44, n. 6: 49-55. http://dx.doi.org/10.2307/975661

NORD, J. H.; NORD, G. D. (1995): "MIS research: Journal status and analysis", Information and Management, vol. 29, n. 1: 29-42. http://dx.doi.org/10.1016/03787206(95)00010-T

NOUR, M. (1985): "A quantitative analysis of the research articles published in core library journals of 1980", Library and Information Science Research, vol. 7, n. 3: 261273.

OSBORNE, D. (2009). "Delivering Public Services: Are We Asking the Right Questions?", Public Money \& Management, vol. 29, n. 1: 5-7.

OSBORNE, D. (2010). "Delivering Public Services: Time for a New Theory?", Public Management Review, vol. 12, n. 1: 1-10. http://dx.doi.org/10.1080/14719030903495232

PLÜMPER, T.; RADAELLI, C. M. (2004): "Publish or perish? Publications and citations of Italian political scientists in international political science journals, 1990-2002", Journal of European Public Policy, vol. 11, n. 6: 1112-1127. http://dx.doi.org/10.1080/1 $\underline{350176042000298138}$

PRITCHARD, A. (1969): "Statistical bibliography or bibliometrics", Journal of Documentation, vol. 25, n. 4: 348-349.

RAGAB, E. A. (2005): "The Influence of Demographic and Socio-conomic Factors upon Using Information Technology Among More, Moderate, and Less Developed Countries in the Globe", The International Journal of Sociology and Social Policy, vol. 25, n. 10/11:37-53. http://dx.doi.org/10.1108/014433330510791379 
RICE, T. W.; MCCORMICK, J. M.; BERGMANN, B. D. (2002): "Graduate training, current affiliation and publishing books in political science", Public Science and Politics, vol. 35, n. 4: 751-755.

SERRANO-CINCA, C.; RUEDA-TOMAS, M.; PORTILLO-TARRAGONA, P. (2009): "Determinants of e-government extension", Online Information Review, vol. 33, n. 3: 476-498. http://dx.doi.org/10.1108/14684520910969916

SHIM, D. C.; EOM, T. H. (2009): “Anticorruption effects of information communication and technology (ICT) and social capital", International Review of Administrative Review, vol. 75, n. 1: 99-116.

STALLINGS, R. A.; FERRIS, J. M. (1988): "Public Administration Research: Work in PAR, 1940-1984", Public Administration Review, vol. 48, n. 1: 580-585. http://dx.doi.org $\underline{110.2307 / 975522}$

ULlAH, M.; BUTT, I. F.; HAROON, M. (2008): "The Journal of Ayub Medical College: a 10 year bibliometric study", Health Information and Libraries Journal, vol. 25, n. 2: 116-124. http://dx.doi.org/10.1111/j.1471-1842.2007.00757.x

VOCINO, T.; ELLIOTT, R. H. (1982): "Journal Prestige in Public Administration: A Research Note", Administration and Society, vol. 14, n. 1: 5-14. http://dx.doi.org/10.1177 $\underline{1009539978201400101}$

WEBSTER, J.; WATSON, R. T. (2002): "Analyzing the past to prepare for the future: Writing a Literature Review”, MIS Quarterly, vol. 26, n. 2: 13-23.

WRIGHT, B. E.; MANIGAULT, L. J.; BLACK, T. R. (2004): “Quantitative Research Measurement in Public Administration: An Assessment of Journal Publications", Administration and Society, vol. 35, n. 6: 747-764. http://dx.doi.org/10.1177/009539970 $\underline{3257266}$

YILDIZ, M. (2007): "E-Government research: Reviewing the literature, limitations, and ways forward", Government Information Quarterly, vol. 24, n. 3: 646-665. http://dx.doi.o rg/10.1016/j.giq.2007.01.002 